\title{
Level of Denture Cleanliness Influences the Presence of Denture Stomatitis on Maxillary Denture Bearing-Mucosa
}

\author{
Winatty Krisma, Martha Mozartha, Rani Purba \\ Department of Dental Material, Dentistry Study Program, Faculty of Medicine, Sriwijaya University, Ogan Ilir \\ 30662, South Sumatera, Indonesia \\ Corresponding e-mail to: martha.mozartha@gmail.com
}

\begin{abstract}
Plaque accumulation on internal surface of denture is a common problem among removable denture wearers. Poor denture cleanliness can increase colonization of Candida albicans and cause inflammatory reaction of denture-bearing mucosa, i.e. denture stomatitis. Objective: To find out the effect of denture cleanliness level on denture stomatitis on maxillary denture-bearing mucosa in a group of removable denture wearers who received prosthodontic treatment at Poliklinik Gigi RSMH Palembang and to investigate the denture hygiene habits of removable denture wearers. Methods: Thirty subjects participated in this study. Denture cleanliness level was assessed with disclosing solution to disclose denture plaque on internal surface of maxillary denture. Cleanliness level was graded according to Budtz-Jorgensen. Intraoral examination was done to determine any visible signs of denture stomatitis. Data referring to denture hygiene habits of removable denture wearers was collected from interview using questionnaire. Data were analyzed using the Komolgorov-Smirnov test. Results: Result of the study showed that $40 \%$ subjects had poor upper denture cleanliness. Denture stomatitis was observed on maxillary denture-bearing mucosa in $43.3 \%$ subjects. Kolmogorov-Smirnov test showed that there was a significant effect of denture cleanliness level on denture stomatitis on maxillary denture-bearing mucosa $(p<0.05)$. Conclusion: Denture cleanliness level influence the occurence of denture stomatitis on maxillary denture bearing-mucosa in a group of removable denture wearers who received prosthodontic treatment.
\end{abstract}

\begin{abstract}
ABSTRAK
Tingkat kebersihan gigi tiruan mempengaruhi terjadinya denture stomatitis pada mukosa pendukung gigi tiruan rahang atas. Akumulasi plak pada permukaan internal basis gigi tiruan lepas merupakan masalah umum yang dapat ditemukan pada pemakai gigi tiruan lepas. Kebersihan gigi tiruan yang kurang adekuat dapat meningkatkan kolonisasi Candida albicans dan dapat menyebabkan reaksi peradangan pada mukosa pendukung gigi tiruan yaitu denture stomatitis. Tujuan: Menganalisis pengaruh tingkat kebersihan gigi tiruan terhadap terjadinya denture stomatitis pada mukosa pendukung gigi tiruan rahang atas (RA) pada pasien yang menerima perawatan gigi tiruan lepas di Poliklinik Gigi RS Moh. Hoesin (RSMH) Palembang serta untuk mengetahui bagaimana cara pasien dalam menjaga kebersihan gigi tiruan lepas. Metode: Subjek penelitian berjumlah sebanyak 30 orang. Tingkat kebersihan gigi tiruan diukur melalui pewarnaan plak pada permukaan internal basis gigi tiruan RA dengan menggunakan disclosing solution dan dinilai dengan menggunakan kriteria kebersihan gigi tiruan Budtz-Jorgensen. Pemeriksaan klinis dilakukan untuk melihat ada atau tidaknya denture stomatitis. Data mengenai cara pasien dalam menjaga kebersihan gigi tiruan lepas didapat dari hasil wawancara. Data dianalisis menggunakan uji alternatif Kolmogorov-Smirnov. Hasil: 40\% subjek penelitian memiliki kebersihan gigi tiruan RA yang buruk. Denture stomatitis ditemukan di mukosa pendukung gigi tiruan RA pada 43,3\% subjek penelitian. Hasil uji alternatif Kolmogorov-Smirnov menunjukkan bahwa tingkat kebersihan gigi tiruan berpengaruh secara bermakna terhadap terjadinya denture stomatitis di mukosa pendukung gigi tiruan rahang atas $(p<0,05)$. Simpulan: Tingkat kebersihan gigi tiruan mempengaruhi terjadinya denture stomatitis di mukosa pendukung gigi tiruan rahang atas pada pasien yang menerima perawatan gigi tiruan lepas.
\end{abstract}

Key word: denture cleanliness, denture plaque, denture stomatitis, removable denture 


\section{PENDAHULUAN}

Gigi tiruan lepas merupakan perawatan untuk menggantikan kehilangan gigi baik di rahang atas (RA) maupun rahang bawah (RB) dengan desain yang dapat dilepas dan dipasang sendiri oleh pemakai. Gigi tiruan lepas terbagi menjadi gigi tiruan penuh (GTP) dan gigi tiruan sebagian lepas (GTSL) yang terdiri dari basis yang menutupi mukosa mulut dengan anasir gigi tiruan yang melekat pada basis tersebut. ${ }^{1,2}$

Permukaan internal basis gigi tiruan yang selalu berkontak dengan mukosa mulut dapat menjadi tempat yang ideal untuk pembentukan plak gigi tiruan. ${ }^{3}$ Selain itu, kebersihan gigi tiruan yang kurang adekuat dapat meningkatkan akumulasi plak pada permukaan tersebut. ${ }^{4}$ Salah satu mikroorganisme yang dapat ditemukan pada plak gigi tiruan adalah jamur Candida albicans. ${ }^{5}$ Candida albicans diketahui sebagai mikroorganisme patogen yang mampu menghasilkan enzim hidrolitik yang bersifat toksik dan dapat menyebabkan terjadinya denture stomatitis. ${ }^{6}$

Denture stomatitis merupakan suatu reaksi peradangan pada jaringan lunak pendukung gigi tiruan. Berdasarkan klasifikasi Newton terdapat 3 tipe denture stomatitis, yaitu bintik merah (pinpoint hyperemia) yang terlokalisir, eritema difus, dan hiperplasia papila. Reaksi peradangan ini lebih sering ditemukan pada mukosa pendukung gigi tiruan rahang atas.?

Denture stomatitis dapat dicegah dengan kebersihan gigi tiruan yang adekuat. ${ }^{8}$ Terdapat beberapa metode pembersihan gigi tiruan yang dapat dilakukan oleh pemakai gigi tiruan, yaitu dengan penyikatan (mekanis), perendaman (kimiawi) atau kombinasi keduanya. ${ }^{9}$ Metode pembersihan gigi tiruan yang baik harus didukung dengan praktek pemakai gigi tiruan dalam menjaga kebersihan gigi tiruan dan rongga mulut, seperti frekuensi pembersihan gigi tiruan secara teratur, melepas gigi tiruan di malam hari ketika tidur serta membersihkan mukosa pendukung gigi tiruan.

Penelitian mengenai tingkat kebersihan gigi tiruan pada pemakai gigi tiruan lepas telah banyak dilakukan di negara lain. Sejauh ini belum ada penelitian mengenai tingkat kebersihan gigi tiruan pada pasien yang mendapatkan perawatan gigi tiruan lepas di Poliklinik Gigi Rumah Sakit Umum Pusat Mohammad Hoesin (RSMH) Palembang. Oleh karena itu, tujuan dari penelitian ini adalah untuk mengetahui tingkat kebersihan gigi tiruan rahang atas pada pasien gigi tiruan lepas di Poliklinik Gigi RSMH Palembang serta pengaruhnya terhadap terjadinya denture stomatitis di mukosa pendukung gigi tiruan rahang atas. Penelitian ini juga bertujuan untuk mengetahui bagaimana cara pasien gigi tiruan menjaga kebersihan gigi tiruan lepas.

\section{METODE}

Studi potong lintang dilakukan pada 30 orang pasien yang menerima perawatan gigi tiruan lepas di Poliklinik Gigi RSMH Palembang. Penelitian ini sebelumnya telah mendapatkan sertifikat persetujuan etik (ethical clearance) dari Komisi Etik Penelitian RSMH dan Fakultas Kedokteran Universitas Sriwijaya. Pengambilan subjek penelitian dilakukan dengan metode purposive sampling berdasarkan kriteria inklusi, yaitu antara lain: pasien yang menggunakan gigi tiruan lepas rahang atas dengan basis berbahan dasar resin akrilik (GTP maupun GTSL) dan telah menggunakan gigi tiruan minimal 3 bulan dan maksimal 5 tahun, gigi tiruan memiliki retensi dan stabilisasi yang baik, pasien tidak memiliki riwayat penyakit sistemik, tidak sedang mengkonsumsi antibiotik dan kortikosteroid serta tidak sedang menjalani kemoterapi atau radioterapi pada bagian kepala dan leher.

Tingkat kebersihan gigi tiruan RA diukur melalui pewarnaan plak pada permukaan internal basis gigi tiruan rahang atas dengan disclosing solution. Seluruh permukaan internal basis gigi tiruan RA diolesi disclosing solution, lalu dibiarkan selama 1 menit. Kemudian gigi tiruan dibersihkan dengan air untuk melihat pewarnaan plak pada permukaan internal basis gigi tiruan RA. Tingkat akumulasi plak dinilai dengan menggunakan kriteria kebersihan gigi tiruan BudtzJorgensen yang terdiri dari baik (tidak ada plak atau hanya berupa bintik-bintik pewarnaan plak), sedang (plak meluas menutupi kurang dari setengah permukaan internal basis gigi tiruan), buruk (hampir seluruh permukaan internal basis gigi tiruan tertutupi plak). ${ }^{10}$

Subjek penelitian diwawancarai mengenai cara dalam menjaga kebersihan gigi tiruan dengan menggunakan daftar pertanyaan yang diadaptasi dari penelitian sebelumnya (Gambar 1). ${ }^{11}$ Setelah wawancara dilakukan, mukosa oral rahang atas yang tertutupi basis gigi tiruan diperiksa untuk melihat ada atau tidaknya peradangan berdasarkan klasifikasi denture stomatitis menurut Newton. ${ }^{12}$

Uji non-parametrik Chi-square $(\alpha<0,05)$ dilakukan untuk mengetahui pengaruh tingkat kebersihan gigi tiruan terhadap terjadinya denture stomatitis. Syarat uji Chi-square adalah sel yang mempunyai nilai expected kurang dari 5, maksimal 20\% dari jumlah sel. Jika syarat uji Chi-square tidak terpenuhi, maka dipakai uji alternatif yaitu dengan uji Kolmogorov-smirnov $\cdot^{13}$ Hasil perhitungan uji Chi-square dengan tabulasi silang $2 \times 3$ menunjukkan bahwa terdapat 3 sel dengan nilai ekspektasi kurang dari 5. Hal ini tidak memenuhi syarat untuk dilakukan uji Chi-Square, oleh karena itu dilakukan uji Komolgorovsmirnov untuk mengetahui pengaruh tingkat kebersihan gigi tiruan terhadap terjadinya denture stomatitis. 
1. Apakah Anda mendapatkan instruksi dari dokter gigi mengena cara menjaga kebersihan gigi?

$$
\square \text { Ya }
$$

\section{$\square$ Tidak}

2. Kapan saja Anda menggunakan gigi tiruan Anda?

$\square$ Sepanjang hari malam hari ketika tidur

$\square$ Sepanjang hari

3. Apakah Anda membersihkan gigi tiruan Anda secara rutin tiap harinya, jika iya berapa kali sehari Anda membersihkannya? (Jika tidak jawab pertanyaan nomor 4)

$$
\begin{aligned}
& \square 1 \text { x sehari } \\
& \square 2 \text { x sehari } \\
& \square 3 \text { x sehari }
\end{aligned}
$$

4. Berapa kali seminggu Anda membersihkan gigi tiruan Anda

$$
\begin{aligned}
& \square 1 \text { x seminggu } \\
& \square 2 \times \text { seminggu } \\
& \square 3 \text { x seminggu }
\end{aligned}
$$

5. Bagaimana Anda membersihkan gigi tiruan?

$\square$ Hanya dengan menggunakan air menggunakan sikat gigi dan air

$\square$ Menyikat gigi tiruan dengan menggunakan sikat gigi dan pasta gigi

6. Apakah Anda juga merendam gigi tiruan Anda dalam larutan pembersih gigi tiruan

$\square$ Ya

\section{$\square$ Tidak}

7. Apakah Anda mengalami kesulitan dalam membersihkan gigi tiruan?

$\square$ Ya, pada bagian apa? ...

$\square$ Tidak

$\square 3 \times$ sehari $\square$ Menyikat gigi tiruan dengan

Gambar 1. Daftar pertanyaan mengenai cara menjaga kebersihan gigitiruan

\section{HASIL}

Pasien yang telah memenuhi kriteria yang ditentukan dan menyetujui untuk diikutsertakan sebagai subjek penelitian berjumlah 30 orang. Subjek penelitian terdiri dari 20 orang subjek penelitian menggunakan gigi tiruan penuh RA dan 10 orang subjek penelitian menggunakan gigi tiruan sebagian lepas RB.

Hasil pemeriksaan tingkat kebersihan gigi tiruan RA dengan disclosing solution menunjukkan bahwa 7 $(23,3 \%)$ orang memiliki tingkat kebersihan gigi tiruan baik, 11 orang $(36,7 \%)$ memiliki tingkat kebersihan gigi tiruan sedang, dan 12 orang (40\%) memiliki tingkat kebersihan buruk (Gambar 2 dan Gambar 3). Sedangkan hasil pemeriksaan klinis pada mukosa pendukung gigi tiruan menunjukkan bahwa denture stomatitis ditemukan di mukosa pendukung gigi tiruan RA pada 13 orang subjek penelitian (43,3\%), yang terdiri dari 9 orang dengan tingkat kebersihan GT yang buruk, 3 orang dengan tingkat kebersihan GT yang sedang, dan 1 orang dengan tingkat kebersihan GT yang baik (Gambar 4 dan Gambar 5).

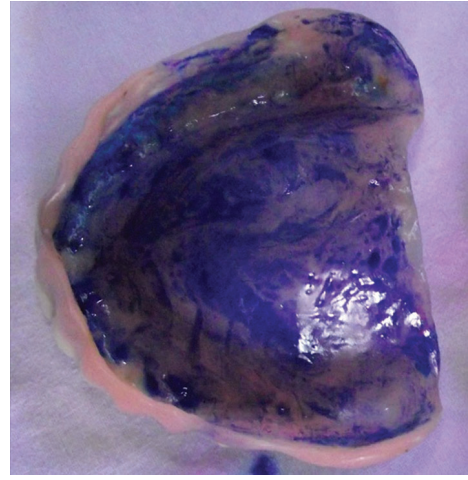

Gambar 2. Permukaan internal basis gigi tiruan penuh RA yang diolesi disclosing solution

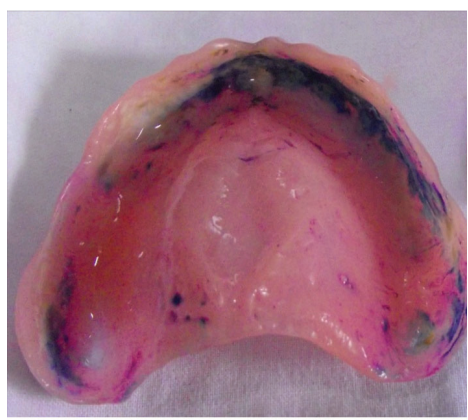

Gambar 3. Akumulasi plak yang terlihat pada permukaan internal basis gigi tiruan penuh RA setelah disclosing solution dibersihkan dengan air

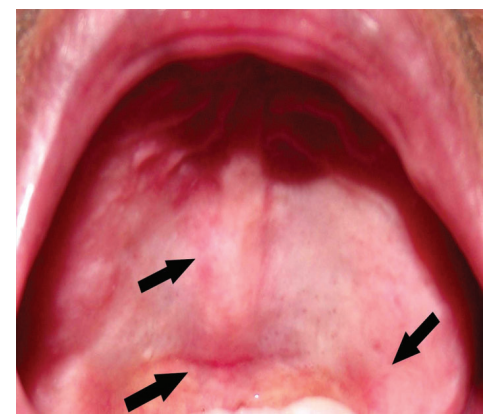

Gambar 4. Denture stomatitis tipe 1, berupa kemerahan yang terlokalisir pada mukosa palatum (tanda panah)

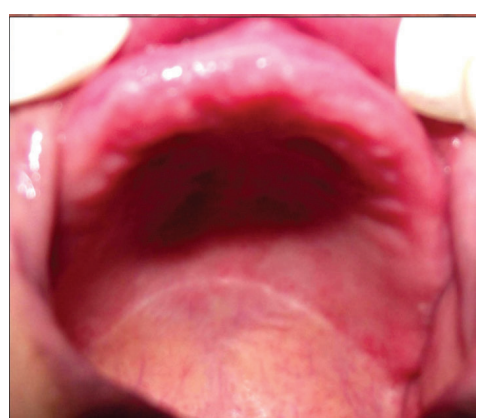

Gambar 5. Denture stomatitis tipe 2, eritema difus pada mukosa rahang atas yang tertutupi permukaan internal basis gigi tiruan lepasan 
Berdasarkan hasil perhitungan uji KolmogorovSmirnov didapatkan $p=0,04$. Hal ini menunjukkan bahwa ada pengaruh tingkat kebersihan gigi tiruan terhadap terjadinya denture stomatitis di mukosa pendukung RA pada pasien gigi tiruan lepas di Poliklinik Gigi RSMH Palembang (Tabel 1).

Tabel 1. Pengaruh tingkat kebersihan gigi tiruan terhadap terjadinya denture stomatitis pada mukosa pendukung gigi tiruan rahang atas*

\begin{tabular}{lrr}
\hline Tingkat Kebersihan & \multicolumn{2}{c}{ Denture stomatitis } \\
\hline & Ada & Tidak ada \\
Baik & 1 & 9 \\
Sedang & 3 & 8 \\
Buruk & 9 & 3 \\
\hline
\end{tabular}

* $\mathrm{X}^{2}$ : terdapat 3 sel dengan nilai ekspektasi $<5$, tidak memenuhi syarat uji Chi-square; Uji alternatif Kolmogorov-Smirnov, $p=0,04$ $(p<0,05)$

Hasil wawancara mengenai praktek dalam menjaga kebersihan gigi tiruan menunjukkan bahwa penyikatan gigi tiruan merupakan metode pembersihan gigi tiruan yang paling banyak dilakukan oleh subjek penelitian yaitu sebanyak $23(77,7 \%)$ orang, namun hanya 6 orang (20\%) yang merendam gigi tiruan dalam larutan pembersih gigi tiruan (Tabel 2). Frekuensi pembersihan gigi tiruan sebanyak $2 \mathrm{x}$ sehari dilaporkan oleh 11 orang subjek penelitian (36,7\%), sementara itu masih ada subjek penelitian yang membersihkan gigi tiruan secara tidak teratur yaitu sebanyak $5(16,6 \%)$ orang. Delapan orang subjek penelitian $(26,7 \%)$ melaporkan mengalami kesulitan dalam hal pembersihan gigi tiruan terutama pada bagian sayap internal labial dan lingual gigi tiruan. Selain itu, berdasarkan hasil wawancara yang telah dilakukan didapatkan bahwa sebanyak 18 orang subjek penelitian (60\%) tetap menggunakan gigi tiruan ketika tidur di malam hari.

Tabel 2. Metode pembersihan gigi tiruan lepasan yang dilakukan subjek penelitian

\begin{tabular}{lrc}
\hline Metode Pembersihan & Jumlah & \% \\
\hline $\begin{array}{l}\text { Hanya dengan air } \\
\text { (dengan perendaman ataupun }\end{array}$ & 7 & 23,3 \\
pembilasan) & & \\
& & \\
Penyikatan & & \\
Sikat + air & 3 & 10,0 \\
Sikat + pasta gigi & 20 & 66,7 \\
& & \\
Perendaman dalam larutan pembersih & & \\
gigi tiruan & & \\
Ya & 6 & 20,0 \\
Tidak & 24 & 80,0 \\
& & \\
Frekuensi pembersihan gigi tiruan & & \\
1x sehari & 6 & 20,0 \\
2x sehari & 11 & 36,7 \\
3x sehari & 8 & 26,7 \\
tidak teratur & 5 & 16,6 \\
\hline
\end{tabular}

Selain cara menjaga kebersihan gigi tiruan, subjek penelitian juga ditanyakan tentang instruksi yang didapat dari operator mengenai pembersihan gigi tiruan. Hasil wawancara menunjukkan bahwa 14 $(46,7 \%)$ orang subjek penelitian mendapatkan instruksi mengenai pembersihan gigi tiruan, sementara 16 $(53,3 \%)$ orang lainnya tidak.

\section{PEMBAHASAN}

Hasil perhitungan statistik dengan uji alternatif Kolmogorov-smirnov menunjukkan bahwa terdapat pengaruh tingkat kebersihan gigi tiruan lepas RA terhadap terjadinya denture stomatitis pada pasien pengguna gigi tiruan lepas di Poliklinik Gigi RSMH Palembang $(p<0,05)$. Hasil penelitian ini serupa dengan hasil penelitian yang menunjukan bahwa ada pengaruh tingkat kebersihan gigi tiruan lepas RA terhadap terjadinya denture stomatitis pada pasien pengguna gigi tiruan lepas di Departemen Prostodontik Rumah Sakit Militer di Yordania. ${ }^{14}$

Gigi tiruan dengan kebersihan yang buruk menunjukkan tingkat akumulasi plak yang banyak. Candida albicans merupakan salah satu mikroogranisme yang banyak ditemukan pada plak gigi tiruan dan diketahui sebagai mikroorganisme patogen utama penyebab denture stomatitis. ${ }^{6}$ Candida albicans memiliki kemampuan patogen yaitu dapat menghasilkan enzim aspartil proteinase yang bersifat toksik dan dapat menyebabkan reaksi inflamasi pada mukosa pendukung gigi tiruan. ${ }^{6}$ Enzim ini dihasilkan dan diaktivasi pada lingkungan asam $(\mathrm{pH}<4) .{ }^{15}$ Penggunaan gigi tiruan secara terusmenerus, yaitu sepanjang hari hingga malam hari ketika tidur seperti yang ditemukan pada $60 \%$ subjek penelitian, dapat menyebabkan keadaan di bawah permukaan basis gigi tiruan bersifat asam. Hal ini dapat memberikan keuntungan bagi Candida albicans untuk menghasilkan enzim aspartil proteinase dan menyebabkan reaksi inflamasi. ${ }^{15}$

Permukaan internal basis gigi tiruan (denture fitting surface) merupakan bagian yang paling banyak ditemukan kolonisasi Candida albicans. Hal ini disebabkan karena permukaan internal basis gigi tiruan resin akrilik yang kasar sehingga memudahkan Candida albicans untuk melekat pada permukaan tersebut. Oleh karena itulah pembersihan gigi tiruan yang kurang adekuat dapat meningkatkan kolonisasi dan pertumbuhan Candida albicans. ${ }^{16}$

Tingginya persentase subjek penelitian dengan tingkat kebersihan gigi tiruan yang buruk dapat dihubungkan dengan pembersihan gigi tiruan yang tidak adekuat. Kombinasi pembersihan gigi tiruan secara mekanis dan kimiawi merupakan metode pembersihan yang efektif untuk mengontrol plak pada gigi tiruan. ${ }^{16}$ Namun pada penelitian ini, sebagian besar subjek penelitian 
membersihkan gigi tiruan dengan cara penyikatan dan hanya $20 \%$ yang melakukan perendaman dalam larutan pembersih. Sedangkan, membersihkan gigi tiruan hanya dengan penyikatan diketahui kurang efektif untuk mengontrol plak pada gigi tiruan, terutama pada permukaan gigi tiruan yang sulit dijangkau. ${ }^{11}$ Seperti pada hasil penelitian ini diketahui bahwa $26,7 \%$ subjek penelitian yang membersihkan gigi tiruan dengan cara penyikatan mengalami kesulitan untuk membersihkan bagian sayap internal labial dan bukal gigi tiruan.

Meskipun bersifat asimtomatis dan pasien tidak menyadari tentang keadaan ini, denture stomatitis merupakan keadaan mukosa mulut yang tidak sehat. Oleh karena itu, perlu dilakukan tindakan pencegahan seperti dengan menjaga kebersihan gigi tiruan. Retensi dan stabilisasi gigi tiruan yang baik pasca insersi bukan merupakan tahap akhir dari perawatan gigi tiruan, namun merupakan suatu awal hubungan yang panjang antara operator dan pasien untuk menjaga kesehatan jaringan rongga mulut. ${ }^{10,17}$ Pada penelitian ini, 53,3\% subjek penelitian melaporkan tidak mendapatkan instruksi mengenai cara pembersihan gigi tiruan. Pemberian edukasi, instruksi dan motivasi merupakan tahap penting yang tidak boleh diabaikan dan harus diberikan sejak awal perawatan.

\section{DAFTAR PUSTAKA}

1. Nallaswamy D. Textbook of prosthodontics. New Delhi: Jaypee Brother Medical Publisher; 2003.

2. Fraunhofer JA. Dental material at a glance. USA: Wiley-BlackWell; 2010. p.17.

3. Keng SB, Lim M. Denture plaque distribution and the effectiveness of a perborate-containing denture cleanser. Quintessence Int. 1996;27:341-5.

4. Basker RM, Davenport JC, Thomason JM. Prosthetic treatment of the edentulous patient. 5th ed. USA: Wiley-BlackWell, 2011.

5. Budtz-Jørgensen E. Ecology of Candida-associated denture stomatitis. Microbial Ecol Health Dis. 2000;12:170-85.

6. Bhat V, Sharma SM, VShety, Shastry CS, Rao V. Extracelluler enzymes of Candida albicans and their role in development of denture stomatitis, a review. JIADS. 2011;2:26-30.

7. Elham E, Taraf, H, de Grandmont P, Gauthier G, de Koninck L, et al. The association of denture stomatitis and partial removable dental prostheses: a systematic review. Int J Prosthodont. 2012;25:113-9.

8. Coulthwaite L, Verran J. Potential pathogenic aspect of denture plaque. Br J Biomed Sci. 2007;64:180-9.

9. Shay K. Denture hygiene: a review and update. J Contemp Dent Prac. 2000;1:1-8.

10. Hadjieva H, Dimova M, Todorov S. Stomatitis prosthetica-a polyetiologic disorder. JIMAB. 2006; 12:38-41.

11. Patel BI, Madan G, Patel B, Solanki K, Chavda R. Behaviours and hygiene habits of a sample population of complete denture wearers in Ahmedabad. $\mathrm{JIOH}$. 2012;4:30-7.

12. Zissis A, Yannikakis S, Harrison A. Comparison of denture stomatitis prevalence in 2 population groups. Int J Prosthodont. 2006;19:621-5.

13. Dahlan S. Statistik untuk kedokteran dan kesehatan: deskriptif, bivariat, dan multivariat, dilengkapi aplikasi dengan menggunakan SPSS. Jakarta: Salemba Medika; 2013.Indonesian.

14. Nimri GM. The effect of denture stability, occlusion, oral hygiene and smoking on denture-induces stomatitis. SDJ. 2008;20:156-62.

15. Williams DW, Kuriyama T, Silva S, Malic S, Lewis MA. Candida biofilms and oral candidosis: treatment and prevention. Periodontol. 2011;55:250-65.

16. Pesee S, Pratipsawangwong B, Pesee C. Prevalence and risk factors associated with denture stomatitis. CU Dent J. 201235:189-200.

17. Peracini A, Andrade IM, Paranhos H de F, Silva $\mathrm{CH}$, de Souza RF. Behaviors and hygiene habits of complete denture wearers. Braz Dent J. 2010; 21:24752. 